\title{
Politics of Social Reformation in NWFP (KPK) - An Estimate of Khan Abdul Ghaffar Khan (1890-1988)'s Educational Philosophy
}

\author{
Dr. Mazher Hussain ${ }^{1}$, Muhammad Anwar ${ }^{2}$, Mian Saeed Ahmad ${ }^{3}$, Mian Muhammad Ahmad ${ }^{4}$, Azra Nasreen ${ }^{5}$ \\ ${ }^{1}$ Lecturer, Department of History, the Islamia University of Bahawalpur, Pakistan. \\ ${ }^{2} \mathrm{PhD}$ Scholar, Department of History, the Islamia University of Bahawalpur, Pakistan. \\ ${ }^{3} \mathrm{PhD}$ Scholar, Department of History, the Islamia University of Bahawalpur, Pakistan. \\ ${ }^{4} \mathrm{PhD}$ Scholar, Department of History, the Islamia University of Bahawalpur, Pakistan. \\ ${ }^{5} \mathrm{PhD}$ Scholar, Department of History, the Islamia University of Bahawalpur, Pakistan. \\ Correspondence: Dr. Mazher Hussain, the Islamia University of Bahawalpur, Pakistan. Tel: +92-62-9255463, \\ $+92-321-7593576$
}

Received: March 17, 2016

doi:10.11114/ijsss.v4i6.1466
Accepted: April7, $2016 \quad$ Available online: April 20, 2016

URL: http://dx.doi.org/10.11114/ijsss.v4i6.1466

\begin{abstract}
In the history of North-West Frontier Province (NWFP; renamed as Khyber Pakhtunkhwa through $18^{\text {th }}$ Amendment on 15 April 2010), many renowned personalities played their role for the awakening of the masses. Among them, Khan Abdul Ghaffar Khan (alias Bacha Khan) occupies a prominent place. The history of KPK would remain incomplete without the notion of services rendered by Bacha Khan. He played his role in a dignified manner in politics, social and educational field. It is a matter of fact that continuous invasions over Pakhtuns region greatly reduced the literacy rate among Pakhtuns which resulted in backwardness of the province. Consequently intermingling of evil customs into Pakhtun society in the name of Islam became the fate of the society. They were having a little knowledge of the religion. Mullahs, the religious leaders, also did nothing for the revival of Islam and Pakhtun society. Pakhtuns were living miserably and none was ready to come forward for the revival of this society. At the same time there came Bacha Khan on the scene and he accepted the challenge of the revival of Pakhtun society. This article highlights the facts that how Bacha Khan used education as a weapon for the revival of Pakhtun society of KPK. He not only made steps to flourish education among Pakhtuns but also tried his best to refrain the Pakhtuns from believing the evil customs and their practices. This article also mentions the institutions which were established by Bacha Khan to achieve his motives.
\end{abstract}

Keywords: Pakhtun, Islam, Social Reformation, Madrassa Education, Non-violence

\section{Introduction}

Strategically, Pakhtunkhawa is an important region of South Asia. The region and its residents are wrongly known for their violent nature. The people who labeled Pakhtuns have ignored the catalyst which makes them violent. Most of the decisions regarding the region particularly political decisions were taken in violent manners that compel them to respond violently. To normalize the violent nature of Pakhtuns, Bacha Khan introduced non-violence philosophy. To inject non-violence philosophy in Pakhtuns was not an easy job. Though he faced lot of hurdles but continued his struggle. During his struggle he concluded that education was prerequisite for injecting this philosophy in Pakhtuns. For this purpose he started an educational program to civilize Pakhtuns.

Bacha Khan knew that Pakhtuns believed on education but didn't know the way how to receive it? Three prominent leaders were famous for their struggle to inject education in Pakhtuns. All those three worked separately on their own tactics. Haji Abdul Wahid was one of them. He was famously known as Haji Sahib Turangzai. He worked for educating Pakhtuns. He challenged the British authorities. He introduced a chain of madaris in which both religious and modern education was given but mainly focused on religious education. In this struggle he couldn't take British in confidence. This compelled them to suppress him and his educational plan and they were succeeded by suppressing him and his educational plane. Sahibzada Abdul Qayyum was another who also wished to educate Pakhtuns. He worked closely with British to earn their confidence. After earning confidence he established an institution 'Dar-ul-Ulum Islamia' (Islamia College) in 1913. At last but not least another personality also tried to educate Pakhtuns was Khan Abdul 
Ghaffar Khan, famously known as Bacha Khan. He wanted to throw away the violent label from Pakhtuns. For this purpose, he reintroduced the non-violence philosophy of Islam. To inject non-violence philosophy, he visited the entire region but lack of education created hurdles for him. Form his visits he concluded that education is prerequisite for injecting this philosophy in Pakhtuns. So he introduced his own educational philosophy by keeping balance in religious and modern education. British couldn't wish to allow him to educate Pakhtun in his style and broke all type of miseries upon him but he stood firm and faces all those with courage of non-violence.

\section{Pakhtun Tendency toward Education}

Khyber (Note 1) Pakhtunkhawa and nearby FATA is the only earthly way to the Indian Sub-continent because from all other side it was surrounded by the sea. That's why most of the invaders used this route to attack the Sub-continent. Resident of the region i.e. Pakhtuns gave tough resistance to invaders. Consistent invasion disturbed them economically, politically and, most important, educationally. The invaders tried to impose their own culture, traditions and religion over Pakhtuns but they couldn't accept it. They only followed Islam as their religion and considered it the only solution of all problems which they faced or facing. They also followed their own customs and tradition. Many of those traditions were conflicting with Islam but due to the lack of Islamic knowledge they considered these acts as Islamic one. Mullahs were their real guides but they were indulged in worldly activities which disturbed Pakhtuns religiously. On other side regular invasion kept them busy and they could not focus on their education which dropped their literacy rate sharply.(Ihsanullah, n.d.) Pakhtuns were ruled indirectly by Mughals, Sikh and the British. Usually, invaders found prominent people within Pakhtuns and ruled through them. All of them tried to impose themselves over Pakhtuns but couldn't succeed, and among them British was the wiser one. They subjugated the Pakhtuns through Sikhs and ruled them indirectly. Fearing from their abilities, British planned to destroy them in every field of life particularly in education.

After capturing most of the territory of Indian Sub-continent, British started their struggle for spreading Christianity. They introduced missionary activities. These missionaries started their activities when they saw that British captured most of the region and overcome the Mullahs. Through those missionary activities British aimed conversion of Pakhtuns to Christianity for defending themselves in the Sub-continent. For this dirty purpose British used the sacred profession of doctors and teachers. They established missionary hospitals and schools in different parts of the region. They penalized the people with the help of Dr. Penal, Dr. Edward Herbert, Dr. Clark and Dr. Pander for missionary activities. By using their professional activities',(Obhrai, 1938, pp. 62-63) Edward Herbert (first British Commissioner of Peshawar) opened Edward Mission School at Peshawar in 1853, and Sir Robert Croft was appointed its first Principal. Initially, it was a primary school but later on was given the status of Higher Secondary. It was open at Reti Bazar near Chowk Yadgar Peshawar and then shifted to a historical building near Kohati Gate. That historical building was initially used by Afghan Sardar brothers SardarYar Muhammad Khan (1823-1829) and his younger brother, Sardar Sultan Muhammad Khan (1831-1834) as a palace. They were the brothers of Afghan King Amir Dost Muhammad Khan. Both worked for Afghan King as Sardars (lords) of the area because at that time this area was under the jurisdiction of Afghan king. Later on this building was used by British as Governor House.(Ihsanullah, n.d.-c)

Edward Mission High School was the pioneer among all the educational institutions in the region. Peoples from all around came and received the education in this school. The school was not only a historical one but had a credit that personalities like Dr. Khan Saib, ex-Chief Minister of Pakhtunkhawa, ex-President of Pakistan, General Yahya Khan, founder of Islamia College Peshawar, Sahibzada Abdul Qayyum Khan, ex-President of Afghanistan, Dr. Najeebullah studied here in this school. ${ }^{1}$ Despite political leaders renowned poet PatrusBukhari also did his matriculation from this school. At last but not the least the renowned Pakhtun leader and founder of famous KhudaiKhidmatgar movement (Note 2), Khan Abdul Ghaffar Khan(Ihsanullah, n.d.) also studied in the school till $5^{\text {th }}$ class. The school also had the honor that initial academic classes of Edward College Peshawar were used to be held in this school for ten years from 1901 to 1910.(Ihsanullah, n.d.) Beside Herbert Edward other also worked individually but their aim was same that is to convert poor masses from Islam to Christianity. These activities disturbed illiterate Pakhtuns and they couldn't differentiate between true and false properly.

To stop such activities someone had to come forward for the rescue of Islam and the revival of Pakhtuns. In such a critical situation a man with charismatic qualities appeared on the hopeless scenario of the region and gave a hope to the society. That man was Haji Abdul Wahid popularly known as Haji Sahib of Turangzai. (Javed, n.d., pp.35-40) He felt that both Sikhs and British wanted to destroy Pakhtuns socially and economically. Pakhtuns were indulged in non-Islamic activities which disturbed their social life. To get rid of those non-Islamic activities, Haji Sahib started a movement for the reformation of Pakhtun society. During that movement he felt that for the success of this movement it 
was important to impart religious education in the innocent masses. For this purpose he opened a chain of Madaris (religious schools) among throughout the Pakhtun region to counteract missionary schools in the region. Those Madaris were popularly known as 'Azad Madaris'. Haji Sahib couldn't establish those Madaris himself but common Pakhtuns established those Madaris with their own funds and Haji Sahib only managed these Madaris.(Javed, n.d., p.48)The number of these Madaris is ambiguous, the British record suggested it 34 but other sources place them 72, 120 and 150 respectively.(Toru, 2005, p.7) For these Azad schools-cum-madaris eleven were established at Charsadda, one school at Tehkal Payan Peshawar, eight in Sawabi, four at Nowshehra, eight in Mardan and few others at different places of the region. Most of these schools-cum-madaris were established in mosques. The salary of the teachers of these schools was more than the missionary school teachers.(Javed, n.d., pp.78-80) The whole administration of the Madaris was controlled from Madrasa Gaddar of Mardan. MaulviTaj Muhammad Khan of Bughdada was the Muhtamim (Chairman) of that Madrasa and from there he controlled the whole Madaris.(Javed, n.d., p.61) These Madaris aimed three main objectives which were as follows:

a) The freedom of the innocent pakhtuns of the region who victimized by the Sikhs and the British. They will also continue to educate their children to raise them from the level of brute.

b) To save the poor Pakhtuns from the Christian missionaries.

c) With the help of education in Azad Madaris, to trained the young Pakhtuns as freedom fighters.(Javed, n.d., p.67)

Haji Sahib himself used to inspect the schools every month, and inquired the education brilliance of both the students and the teachers. On full satisfaction, in jubilation he announced prizes both students and their teachers. There was no fee structure in these schools. The system was going very well which annoyed the British and they opened a war against him and his schools. He was arrested in 1910 and sent to the jail. This forced him to leave the settled area and migrated to Mohmand Agency where he lived till his death in1937.(Khan, 1983, p.66)

\section{Bacha Khan Joined the Squad}

Migration of Haji Sahib disturbed his educational plan. Though his disciples reopened these schools but couldn't maintain that system which was introduced by Haji Sahib. It was near that the whole system might flop. In the meantime an admirer of Haji Sahib came forward and took the responsibility of educating Pakhtuns. Khan Abdul Ghaffar Khan was the name of that person and world knows him as Bacha Khan. He was a landlord but knew exactly that what Pakhtuns needed? He was a part of Haji Sahib social reforms movement but greatly impressed by his educational plan. Bacha Khan with the help of Maulvi Abdul Aziz opened a madrasa-cum-school in 1910, at Utmanzai.(Khan, 1983, pp.66-67) The Mullahs opposed the plan by declaring it as a missionary school but they had no real alternative. They opposed Bacha Khan and his colleagues at different occasions. Once Bacha Khan and his colleagues were busy in a village to introduce the masses of their educational system, in the meantime a Mullah named Mullah Chitrali came with his books and gun by saying that:

I am against Bacha Khan and his education which he wants to propagate.

He quoted a few words from the books taught in those schools and said;

What is this? Is it education? It wasn't an education.

He asked Bacha Khan that he came there to decide with book or gun.(Khan, 1983, p.67)

Bacha Khan replied:

As you know that I am not a man of gun but a man of books. As you know better that God and his Prophet allowed us of receiving education. And you people were against the missionary schools then you should arrange your own education system for these innocent Pakhtuns but I know that you people wasn't able to do this. So don't stop us from educating these people.(Khan, 1983, p.67)

It became a routine that Mullah opposed the education system of Bacha Khan and his colleagues. They usually used Islamic education as a tool by saying that in these schools they didn't teach religious education. Like past they also used the religion Islam as a tool against Bacha Khan's education system. They considered the school education as Kufr (Heresy). In this context they propagated a verse among masses.

Those who study at school, do it for the love of money. There is no room for them in paradise; instead they will find themselves in hell."(Begum, n.d.)

It was very difficult for Bacha Khan and his colleagues to take repugnance with those Mullahs because he knew that Pakhtuns were more religious than other nations and they gave complete respect to their religious scholars. They follow them blindly without any hesitation and confirmation. This might damage Bacha Khan's plan of educating Pakhtuns. So he counteracted and resolved the matter by linking it with Haji Sahib of Turangzai madaris chain. Bacha Khan knew 
that Haji Sahib was respected more by Pakhtuns because of his spiritual qualities.(Khan, 1983, p.69) That helped him very much and Mullahs stopped their negative propaganda against Bacha Khan and his education system. This gave a boost to Bacha Khan and his colleagues. The plan was interrupted when British planned to arrest Haji Sahib but he escaped to Mohamand Agency.

\section{Putting Theory into Practice: Establishment of Azad Islamia Schools}

Migration of Haji Sahib to Mohmand Agency and business of Bacha Khan disturbed their educational plan. This was continued till 1920. During that span of time, Bacha Khan visited the whole Pakhtun region. During his visit he noted ignorance and illiteracy among Pakhtuns. From those experiences he concluded that for the revival of Pakhtun society a revolution is needed with the help of leaders and scholars. Education is prerequisite for not only those leaders and scholars but it is also important for common masses. So education was declared prerequisite for all those miseries of Pakhtuns. To educate Pakhtuns, Bacha Khan laid the foundation of Azad Islamia School in 1921 at Utmanzai. In that sacred mission Bacha Khan was supported by his close colleagues like Qazi Attaullah, Mian Ahmad Shah, Muhammad Abbas Khan, Haji Abdul Ghaffar Khan, Taj Muhammad Khan, Abdul Akbar Khan Akbar, Abdullah Shah and Khadim Muhammad Akbar.(Khan, 1983, p.182) Maqsud Jan Khan of Bannu became the first headmaster of that Azad School at Utmanzai. His elder brother Amir Mumtaz Khan joined the school as a teacher. Both these brothers who were studying in B.A left Islamia College(Javed, n.d., pp.70-82) Peshawar during Khilafat Movement. They were gifted by his father Amir Mukhtar Khan to the Azad School of Bacha Khan. When Maqsud Jan left the school to continue his education, his elder brother Amir Mumtaz Khan became the headmaster of this school.(Tendulkar, 1967, p.36) Lack of teaching staff compelled Bacha Khan to teach himself in the school. His both sons Khan Abdul Ghani Khan(Babar, 2005, pp.36-49)and Khan Abdul Wali Khan (Ihsanullah, n.d.-a) were among the first students of that school. At first Ghani Khan was sent to the National High School Peshawar but as Bacha Khan wanted to prove the excellence of these schools, he sent Gani and Wali to his own established school. His message was clear by saying that 'look these schools are so good that I am willing to educate my sons in them.'(Javed, n.d., p.40) The idea of Azad School became so popular among Pakhtuns which was a pleasing moment for the founder. With in no time the number of those schools reached to 50 in different parts of the region.(Umerzai, 1967)On the other hand the British were afraid of Bacha Khan Azad schools. They weren't interested in the uplift of the Pakhtuns. To stop Bacha Khan from such activities they used different tactics. They humiliated his teachers, by giving greed of enough salary and offered them better posts in government schools. If they were not agreed British used to torture their family members and close relatives but couldn't succeed to impress the teachers which might affect the school performance. Within six months Azad schools alarmed the British authorities. Objections were made on Bacha Khan touring of different districts. Chief Commissioner of the Province Sir John Maffey summoned Khan's father and told him;

I have noticed that your son is touring village after village and opening schools. I have also noticed that other people stay quietly at home and do not bother about those things. Ask him to stop this work and stay at home like other people otherwise you both will have face consequences.(Tendulkar, 1967, p.37)

When his father came to home, he told his son that; 'why could not he stay at home like other people?' Bacha Khan replied, 'Father, if someone else stop you from offering prayers, would you advise me to do the same?' 'God forbid', his father said 'offering prayers is a sacred duty.' Bacha Khan replied, 'to me, educating people and serving the nation is as sacred like prayers.' On this his father said, 'I see, you are right. If it is duty, then do it.' Khan's father sent a message to Chief Commissioner by saying that; 'Pakhtuns could not possibly given up their religion and sacred duties for their sake.'(Begum, n.d., p.39) Few days later, Bacha Khan was arrested by refusing to shut down his educational plane. He was arrested under 40 F.C.R. on December, 17, 1921 from Utmanzai when he was busy in making a football ground for the students of the Azad School. After arrest he was asked for surety of good conduct which he refused. He was sentenced three years rigorous imprisonment by taking part in anti-British agitation.(Khan, 1983, pp.190-191)

The Azad School at Utmanzai was rapidly followed by the establishment of branches in other parts of the region especially in Charsaddah, Mardan, Swabi and Nowshehra tehsils. According to Abdul Akbar Khan there were 120 such a schools while Mian Jafar Shah and Abdullah Shah stated that there were only 80 such schools in the region. The official record, however, listed a maximum number of fifty one schools.(Rauf, 2006, p.43) As education was free and the schools were open to all communities, without any prejudice of caste or religion, the school gained popularity with in short span of time. The number of students increased from 140 (April 1921-March 1922) to 221 (April 1922-March 1923); and from 264 (April 1923 -March 1924) to 300 (April 1924-March 1925).(Shah, 1999, p.23) Azad Schools was affiliated with Jamia Millia, Delhi, on December 1, 1923. Jamia Millia conducted its examinations and a number of students after passing matriculation in Azad Schools joined Jamia Millia for further education. The schools mainly followed the Jamia syllabus with necessary modification required by the local environment. Pashto was adopted as medium of instruction but certain subjects were thought in English. As Mathematics books were not available in Pashto so it was thought in English. Urdu was also thought as a subject.(Rauf, 2006, p.43)The curriculum also included 
teaching of the Holy Quran, Hadith, Fiqah, Arabic language and Islamic history to impart religious education in the Pakhtuns. Maulana Muhamamd Israel and Maulvi Shah Rasul were two important members of religious section. Who worked voluntarily with the school(Shah, 1999, p.23) not only these two but most of the staff worked voluntarily and few teachers were paid nominally. In early 30s the salary of the headmaster was Rs. 40 and second headmaster received Rs. 20. Beside free education some time the poor students were supported by providing cloths, books and other requirements.(Rauf, 2006, p.46)

\section{Anjuman-e-Islah Afaghina}

After the establishment of Azad School at Utmanzai, Bacha Khan established a society for the reformation of Pakhtuns in 1921. The name of the society was 'Anjuman-e-Islah Afaghina' (Society for the reformation of Afghans). The society aimed to encourage the economic, social and educational uplift of the Pakhtuns. He stressed upon the Pakhtuns to take on professions for earning money despite wasting their valid time in useless activities. To set an example, Bacha Khan himself opened a shop at Gur Mandi (sugar cane market) and started working by himself in his own fields.(Khan, 1983, pp.187-188) The establishment of this association also aimed to take the responsibility of supervision of Azad schools chain and worked for the opening of other schools. The annual report of 1924-25 of the society summarized its aims and objectives as:

The Anjuman aims at propagating the cause of Islam and imparting national and religious education in the Pashto language to the Muslim community. It has hitherto been found impossible to reform the Afghans in the matter of party feeling and morality under the existing foreign education and law. The Anjuman will try to put a stop to the evil customs which are against the laws of Shariat and have impaired the Pathans financially. (Rauf, 2006, p.37)

The following were elected as office bearers of the Anjuman:
a) Khan Abdul Ghaffar Khan (President)
b) Mian Ahmad Shah (Manager)
c) Mian Abdullah Shah
d) Abdul Akbar Khan Akbar
e) Muhammad Abbas Khan

In the absence of Bacha Khan due to three years imprisonment, the Anjuman elected Abdul Akbar Khan Akbar as President. Later on he was replaced by Haji Abdul Ghaffar Khan as President. Khadim Muhammad Akbar took over as Secretary.(Rauf, 2006, p.37)The Anjuman was divided into three Executive, Advisory and General Committees. The number of the Executive Committee members was eleven, Advisory committee included sixty four and General committee strength was ninety four.(Rauf, 2006, p.37)

In the absence of Bacha Khan, Abdul Akbar Khan Akbar did very well and the Anjuman became popular among the common masses. This couldn't feel the absence of Bacha Khan to the Pakhtuns. He used to guide the office barear of the Anjuman from Jail which intensified his social and educational movement not only among the Pakhtuns dominated areas but in other part of India as well. The Anjuman utilized every single occasion to keep people involved. The association used Azad schools students and teachers effectively for different activities. Along with other students Bacha Khan's sons also took active parts. Once Ghani, aged 9, in his speech demanded from the government that 'why my father is imprisoned, what crime has he committed?' his younger brother Wali, used to recite the Holy Quran on such occasion to catch the audience attention. These activities worked effectively and people replied positively by taking active part in every activity arranged by the Anjuman. Those activities flourished Azad schools. On this Bacha Khan said that: "my imprisonment greatly benefited the Pakhtuns. They become more sympathetic to our Azad School and they gave larger aid."(Tendulkar, 1967, p.45)

After three years imprisonment, Bacha Khan was released. He was warmly welcomed by the teachers and students of Azad School at Utmanzai. A huge gathering was organized by the Anjuman with the help of school management to welcome their leader and founder of Azad schools. For this purpose people from all parts of Pakhtunkhawa were invited. In the gathering Bacha Khan was bestowed the title of "Fakhir-e-Afghan" (Pride of Afghan).(Khan, 1983, p.308) His speech, to the gathering, created passion in the audience which encouraged Bacha Khan and his follower for further propagation of his education plane. To examine and expand Azad school branches, Bacha Khan and Khadim Muhammad Akbar started a visit of all the established schools. Khadim Muhammad Akbar took exams from the students at Azad Schools while Bacha Khan visited the Hujras (place of Pakhtuns' social gathering) of different Khans to preach the importance of education to the illiterate masses. Bacha Khan was succeeded to a large extent in his mission. On the other hand British were feared from the charismatic personality of Bacha Khan and his educational plane. They tried every possible opportunity to stop him from doing so but can't succeed to stop him. This compelled 
the British to find out local landlords, Mullahs and educated people to flop the Bacha Khan educational plane. Most of those were studied in missionary schools. They started their activities to educate masses against Bacha Khan educational system. They used every single place like mosques, Hujras and other social and religious gathering to aware the people from the bad impacts of Bacha Khan's education system on Pakhtun society. They guided the people by saying that: if you people educate your off spring's in those schools which were founded by Bacha Khan then who will give them the certificates and government jobs?(Khan, 1983, pp.310-311)

The masses had the awareness about the level of brute and darkness and they rejected all those people and follow Bacha Khan and his education system blindly. Their anti-Azad Schools propaganda couldn't work. After failing in anti-Azad schools propaganda, they now started propaganda against Anjuman and succeeded by creating a conflict among the office bearers of the Anjuman. Mian Maroof Shah, an office bearer of Anjuman was the first victim of that conspiracy. He created differences within the Anjuman and everyone started reasoning with one another which was not a good sign for the welfare of the Anjuman. On this conduct he was terminated from Anjuman but his seedling of conflict was still in the Anjuman. And the whole conflict was for the downfall of Bacha Khan from the presidency of Anjuman. Bacha Khan tried his best to reunite the Anjuman office bearer but can't succeed. Finally he resigned from the president ship of Anjuman which solved the issue to some extent.(Khan, 1983, pp.317-318)

\section{Organ for Social Reformation: Pakhtun Journal}

Introduction of Pakhtun journal was a great achievement of Bacha Khan. He introduced the journal in a situation when Pakhtuns were kept betrayed and ignorant by British authorities. He started the journal at a time when no one in the region accepted Pashto as a mother tongue of Pakhtuns. Most of the Pakhtuns even educated ones were not aware from the importance of Pashto language and they didn't give any importance to it as their native language. For the propagation of Azad Schools and Anjuman, Bacha Khan visited throughout the Pakhtunkhwa. During his visit he observed that most of the Pakhtuns were illiterate and only a rare amount was literate. He felt that this rare amount of people was not enough to aware the illiterate Pakhtuns. For this he needs more than this percentage. So, he concluded that a journal in their mother tongue i.e. Pashto was necessary.(Tendulkar, 1967, p.50) The journal aimed for educating Pakhtuns in their mother tongue because he noted that Pakhtuns had no love for their own language. Bacha Khan observes that;

"Pakhtuns were not even conscious that Pashto was their language, and wherever they go, they adopt the local language and forget their mother tongue. They did not teach their language to others and did not care to read and write in Pashto. Leave aside the illiterate, when I appealed to the educated pakhtuns to subscribe for and read a Pashto journal for the pakhtuns, they remarked, 'what is there in Pashto worth reading and learning? Surely, I asserted, it is not the fault of the Pashto language. All the existing languages of the other countries were once undeveloped. Men of caliber and dedication nurtured their own languages and raised them to great heights. Have any of us ever made an effort to nurture and to develop the Pashto language? On the contrary, the Mullahs propagated that Pashto was the language of hell, spoken by the people in hell. The Pakhtun community was so ignorant that they did not ask the Mullahs, how they got this information and when did they come out of hell'.(Chand, 1989, p.38)

Bacha Khan started 'Pakhtun' journal in May 1928, and he was its editor. Yearly subscription of the journal was Rs. 4. To attract the attention of the students, its yearly subscription was reduced to two and half rupees. The Journal was of medium size having forty pages. Initially the journal was published in Rawalpindi, then in Amritsar and finally at Peshawar.(Chand, 1989, p.39) The journal contained well written articles on different subjects like politics, Pashto literature, Pashto poetry, Islamic history, gender issues, Indian affairs, social problems of Pakhtun society, Afghan affairs and etc. In no time Pakhtun journal became a mouth piece of the Pakhtuns. People not only in Pakhtunkhawa but abroad demanded it. Its circulation was reached from 500 to 3000 which showed how famous was this journal among Pakhtuns.(Shah, 2007, p.65) The main reason of its popularity was that there was no Pashto journal in the region till 1928. Other reason was its topics which mostly covered all fields of life of the region. Its impact was find out from the fact that Afghan king Amanullah ordered; 'that all government servants should learn and read the Pashto language and within three years Pashto should be declared as official language of Afghanistan'.(Khan, 1983, p.335) For this purpose King Amanullah started a Pashto journal named 'Pakhtun Fagh' in Afghanistan under royal patronage. British and their allies (Mullahs, Pirs and Khans) couldn't accept the publicity of Pashto language. And after nine issues Pakhtun Fagh was closed. British with the help of its allies create disturbance in Afghanistan. They declared King Amanullah an infidel and forced him to leave the beloved land.(Tendulkar, 1967, p.55)

\section{Objectives of the "Pakhtun" Journal}

Main objectives of the "Pakhtun" journal were:

a) To create a sense of fraternity and love among the Pakhtuns and to extirpate mutual rivalries. 
b) To create a true spirit of patriotism and motivate them to struggle for freedom and to teach how to fight for it?

c) To promote the cause of the Pashto language and to develop it to meet the scientific and literary demands.

d) To eradicates social evils amongst the Pakhtuns and to advise them against extravagance, ease and luxury so that they might improve their economic lot.

e) To reform their character morally.

f) To teach them the true Islam and to eradicate foolish beliefs.

g) To teach them velour and selfless service and to expose the weaknesses of their national character.

h) To remove all sorts of fanaticism, group rivalries and to create among them qualities of toleration.

i) To warn them of lack of modern education and technical flaws.

j) To root out vicious practices of lying, gambling, drug addiction and bloodshed.(Begum, n.d., pp.45-46)

Pakhtun journal is a multidimensional and multi-purpose journal of Pakhtuns. It not only made Pakhtun aware of social evils but also played an important political role to aware the masses of future dangers. The writers of the journal mostly focused on Pukhtunwali (Note 3), freedom and liberty because that was the demand of that time. Beside this many article were wrote on medical, women and children issues. Mainly journals focused on uplifting of Pashto language and in no time the language developed so much that it can compete with other regional language comfortably. In shortly it was a journal for the reformation of Pakhtun society and people. The journal proved its importance in the ignorant Pakhtun society.

British were first feared from the Azad Schools and then from Pakhtun magazine of Bacha Khan. That's why he was continuously involved in one or other matter and imprisoned him to interrupt his educational plane. They first arrested Bacha Khan on April, 23, 1930 at Nahki under Frontier Crime Regulation (FCR) and imprisoned for three years.(Ihsanullah, n.d.-b) Immediately, after his arrest, Pakhtun Journal publication was also banned. After one year imprisonment he was released and he restarts its publication. In December 1931, Bacha Khan was rearrested and publication of the journal was closed. After his release in 1934, his entrance in Pukhtunkhwa was banned. This couldn't allow him to republish the journal and it was continued till 1937. The ban on Bacha Khan's entry in Pakhtunkhwa was lifted on August, 24, 1937. After his arrival to the province he immediately started publication of Pakhtun journal. Publication of "Pakhtun" continued till October 1942 but was banned once again after his arrest. Soon after his release in 1945, the journal was restarted and it was continued till August 1947. After the creation of Pakistan its publication was permanently banned by the Government of Pakistan and all its available issues were seized. Probably no library or individual who possesses complete file of the Pakhtun journal.(Begum, n.d., pp.48-49) Till the death of Bacha Khan in January 1988, the government of Pakistan couldn't lift the ban of the journal. After his death it was restarted in early years of 90s which was banned later on during Musharraf regime. In 2006 the publication of journal was restarted which is continue till to date.

\section{Conclusion}

Continuous invasions over Pakhtuns region decrease the literacy rate among Pakhtuns which disturbed the society. Lack of knowledge, particularly religious knowledge, intermingle the evil customs in Pakhtun society on the name of Islam. They knew nothing about their own religion of Islam and follow it blindly. Their Mullahs to whom Pakhtun gives complete respect also did nothing for the revival of Islam and Pakhtun society. Pakhtuns forget the lesson of self esteem, love, peace and non-violence. They follow infidel ways and give it the sacred name of Islam. Due to those customs and traditions Pakhtuns live miserably. No one was ready there to come forward for the revival of this society.

In such a critical moment Bacha Khan came forward for the revival of Pakhtun society. After complete observation of the Pakhtun society he concluded that revolutionary steps would needed for the revival of this society otherwise Pakhtun nation would be destroyed. He felt that revolution needed scholars and educationists which weren't available among Pakhtuns. He started struggle for educating Pakhtuns to find out like-minded people. In his educational plane he mainly focused on religious education because of their close affiliation with the religion of Islam. Imparting religious education also aimed to extend their religious knowledge. Lack of religious education mixed the evil customs and traditions in Pakhtun society on the sacred name of Islam. All those three leaders had same motive but their ways were entirely different form each other which was the main cause of the failure of those movements. If they all three worked together it would be a different scenario in educational arena of the region.

Bacha Khan used education as a weapon for the revival of Pakhtuns. Bacha Khan concluded that education is the only solution of all those miseries of Pakhtuns. He not only educated Pakhtuns but also taught the ways of living to Pakhtun. He tried to eradicate the evil and un-Islamic customs from Pakhtun society which is the main educational contribution 
of Bacha Khan. He taught the real lesson of non-violence to Pakhtuns, is the real way of living. He proved all from his actions which he wants to teach to Pakhtuns.

\section{References}

Babar, S. (2005). Strains of Romanticism in Abdul Ghani Khan and John Keats Poetry: A Comparative Study. Pashto Academy, University of Peshawar.

Begum, A. (n.d.). Abdul Ghaffar Khan as a Social Reformer. Peshawar: Pakistan Study Centre University of Peshawar.

Chand, A. (1989). India, Pakistan and Afghanistan; A Study of Freedom Struggle and Abdul Ghaffar Khan. New Delhi: Commonwealth Publishers.

Ihsanullah. (n.d.-a). Chronology of Khan Abdul Wali Khan - Awami National Party. Retrieved April 15, 2016, from http://awaminationalparty.org/main/?p=2810

Ihsanullah. (n.d.-b). Chronology: Khan Abdul Ghaffar Khan: 1889-1988 - Awami National Party. Retrieved April 15, 2016, from http://awaminationalparty.org/main/?p=2647

Ihsanullah. (n.d.-c). Edward Mission Higher Secondary School Peshawar - The KhyberWatch. Retrieved April 15, 2016, from http://khyberwatch.com/main/?p=673

Javed, A. (n.d.). Barsaghir ki Tehrik-e-Azadi ka ek Azeem Mujahid Haji Sahib Turangzai. Lahore: Idara-e-Tehqeeq wu Tasneef.

Khan, K. A. G. (1983). Zama Jwand au Jadujuhad. Ministry of Information Afghanistan.

Obhrai, R. B. D. C. (1938). The Evolution of North-West Frontier Province. Peshawar: Saeed Book Bank.

Rauf, A. (2006). Socio-Educational Reform Movements in NWFP- A Case Study of Anjuman-i-Islahul Afaghina. Pakistan Journal of History and Culture, Quaid-E-Azam University, Islamabad, XXVII(2, July-December,).

Shah, D. S. W. A. (1999). Ethnicity, Islam, and Nationalism; Muslim Politics in the North -West Frontier Province 1937-1947. Karachi: Oxford University Press.

Shah, D. S. W. A. (2007). North West Frontier Province: History and Politics. Islamabad, National Institute of Historical and Cultural Rsearch.

Tendulkar, D. G. (1967). Abdul Ghaffar Khan; Faith is a Battle. Bombay: Gandhi Peace Foundation.

Toru, E. D. P. K., \& D. F.-R. M. (2005). Celebrities of NWFP. Peshawar: Pakistan Study Centre.

Umerzai, A. A. K. (1967). Adabi Panga. Peshawar.

\section{Notes}

1. Khyber Pakhtunkhwa (abbreviated as KP) is one of the four provinces of Pakistan, located in the northwestern region of the country. It was formerly known as North-West Frontier Province (NWFP), commonly called Sarhad in Urdu, which means "frontier." Its provincial capital and largest city is Peshawar, followed by Mardan. It shares borders with the Federally Administered Tribal Areas to the west; Gilgit-Baltistan to the northeast; Azad Kashmir, Islamabad and Punjab to the east and southeast. Khyber Pakhtunkhwa does not share a border with Baluchistan which lies to its southwest. Khyber Pakhtunkhwa also shares an international border with the Afghanistan, connected through the Khyber Pass.

2. The famous Khudai Khidmatgar Movement was started by Bacha Khan for reformation of Pakhtun society in 1929 . Initially it was social reform movement but harsh attitude of British it got a shape of political movement. The foundation of the movement was kept by Bacha Khan on the instigation of Muhammad Akbar Khan, Sarfaraz Khan and Hijab Gul of Utmanzi. Sarfaraz Khan s/o Sultan Muhammad Khan of Utmanzai was elected as a first commander-in-Chief of the movement. Prof. Farhad Jan, Khudai Khidmatgar Movement in NWFP; its Nature and Direction, pp. 37, 41

3. Pukhtoonwali means the unwritten rules and code of life of the Pakhtuns. It includes strict rules of hospitality, revenge, honor etc.

\section{$(\mathrm{cc}) \mathrm{Br}$}

This work is licensed under a Creative Commons Attribution 3.0 License. 